\title{
Salt stress and exogenous application of hydrogen peroxide on photosynthetic parameters of soursop
}

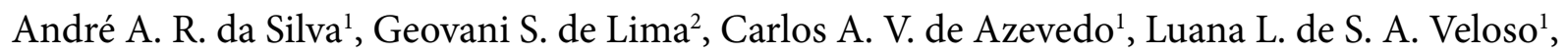 \\ Hans R. Gheyi ${ }^{3} \&$ Lauriane A. dos A. Soares ${ }^{2}$
}

\begin{abstract}
${ }^{1}$ Universidade Federal de Campina Grande/Centro de Tecnologia e Recursos Naturais/Programa de Pós-Graduação em Engenharia Agrícola. Campina Grande, PB, Brasil. E-mail: andrealisson_cgpb@hotmail.com (Corresponding author) - ORCID: 0000-0001-9453-1192; cvieiradeazevedo@gmail.com - ORCID: 0000-0001-7336-1243; luana_lucas_15@hotmail.com - ORCID: 0000-0003-0537-7985

${ }^{2}$ Universidade Federal de Campina Grande/Centro de Ciências e Tecnologia Agroalimentar/Programa de Pós-Graduação em Horticultura Tropical. Pombal, PB, Brasil. E-mail: geovani.soares@pq.cnpq.br - ORCID: 0000-0001-9960-1858; lauriane.soares@pq.cnpq.br - ORCID: 0000-0002-7689-9628 ${ }^{3}$ Universidade Federal do Recôncavo da Bahia/Núcleo de Engenharia de Água e Solo. Cruz das Almas, BA, Brasil. E-mail: hans@pq.cnpq.br - ORCID: 0000-0002-1066-0315
\end{abstract}

\begin{abstract}
This study aimed to evaluate the gas exchanges and photosynthetic pigments of soursop seedlings cv. 'Morada Nova' irrigated with saline waters and subjected to exogenous application of hydrogen peroxide by seed soaking and foliar spraying. The study was carried out using plastic bags under greenhouse conditions at the Center of Technology and Natural Resources of the Federal University of Campina Grande, PB, Brazil, using a eutrophic Regolithic Neosol of sandy loam texture. Treatments were arranged in a randomized block design, in 5 x 5 factorial scheme, which consisted of five levels of electrical conductivity - ECw $(0.7 ; 1.4 ; 2.1$; 2.8 and $\left.3.5 \mathrm{dS} \mathrm{m}^{-1}\right)$ of irrigation water and five concentrations of hydrogen peroxide $-\mathrm{H}_{2} \mathrm{O}_{2}(0,25,50,75$ and $100 \mu \mathrm{M}$ ), with four replicates and three plants per plot. As the salt stress increased, there were reductions in internal $\mathrm{CO}_{2}$ concentration, instantaneous carboxylation efficiency and water use efficiency, and instantaneous carboxylation efficiency was the most sensitive variable. Hydrogen peroxide at concentrations of 25 and $50 \mu \mathrm{M}$ attenuated the deleterious effects of water salinity on stomatal conductance, $\mathrm{CO}_{2}$ assimilation rate and chlorophyll a content, and the concentration of $25 \mu \mathrm{M}$ was the most efficient. The content of chlorophyll $\mathrm{b}$ and carotenoids of soursop cv. 'Morada Nova' had the deleterious effects caused by the salinity of irrigation water mitigated by the exogenous application of hydrogen peroxide in the concentration of $25 \mu \mathrm{M}$.
\end{abstract}

Key words: Annona muricata L., saline waters, physiology

\section{Estresse salino e aplicação exógena de peróxido de hidrogênio nos parâmetros fotossintéticos da gravioleira}

RESUMO: Objetivou-se com este trabalho avaliar as trocas gasosas e os pigmentos fotossintéticos de mudas de gravioleira cv. Morada Nova irrigadas com águas salinas e submetidas à aplicação exógena de peróxido de hidrogênio via embebição das sementes e pulverizações foliares. O estudo foi conduzido em sacolas plásticas sob condições de casa de vegetação pertencente ao Centro de Tecnologia e Recursos Naturais da Universidade Federal de Campina Grande, PB, utilizando-se um Neossolo Regolítico Eutrófico de textura franco-arenosa. Os tratamentos foram distribuídos no delineamento de blocos casualizados, em arranjo fatorial 5 x 5, sendo cinco níveis de condutividade elétrica da água de irrigação - CEa $\left(0,7 ; 1,4 ; 2,1 ; 2,8\right.$ e 3,5 dS m $\left.{ }^{-1}\right)$ e cinco concentrações de peróxido de hidrogênio - $\mathrm{H}_{2} \mathrm{O}_{2}(0,25,50,75$ e $100 \mu \mathrm{M})$, com quatro repetições e três plantas por parcela. Com o aumento do estresse salino, ocorreu diminuição na concentração interna de $\mathrm{CO}_{2}$, na eficiência instantânea da carboxilação e na eficiência no uso da água, sendo a eficiência instantânea da carboxilação a variável mais sensível. O peróxido de hidrogênio nas concentrações de 25 e $50 \mu \mathrm{M}$ atenuou os efeitos deletérios da salinidade da água sobre a condutância estomática, taxa de assimilação de $\mathrm{CO}_{2}$ e no teor de clorofila a, sendo a concentração de $25 \mu \mathrm{M}$ a mais eficiente. O teor de clorofila b e carotenóides da gravioleira cv. Morada Nova teve os efeitos deletérios causados pela salinidade da água de irrigação mitigados pela aplicação exógena de peróxido de hidrogênio na concentração de $25 \mu \mathrm{M}$.

Palavras-chave: Annona muricata L., águas salinas, fisiologia 


\section{INTRODUCTION}

Soursop is a fruit crop that has stood out for having potential of commercialization in the domestic market, with relevant economic importance and prospects for export, and the northeast region of Brazil is the largest producer (Braga Sobrinho, 2010; Cavalcante et al., 2017). Soursop consumption, either fresh or processed, has increased due to its nutritional importance and forms of use in human diet, besides the medicinal properties of its leaves, fruits, seeds and roots (Freitas et al., 2013).

In the semi-arid region of Northeast Brazil, where the low rainfall levels unevenly distributed along the year are limiting factors for agricultural production, the practice of irrigation is the only way to guarantee a cultivation with water security (Lacerda et al., 2016). However, waters from the sources of this region are mostly saline, which may cause morphological, structural and metabolic modifications in plants (Lima et al., 2016). In addition, the effect of water salinity on crops is variable among species (Brito et al., 2014).

As a result, studies have been conducted using saline waters for cultivation in the Northeast region, for instance of sugar apple (Sá et al., 2015), citrus (Barbosa et al., 2017) and guava (Bezerra et al., 2018). Hence, it is extremely important to conduct research aiming to assess other fruit crops such as soursop, because studies involving the use of saline water in its cultivation are scarce.

In this context, alternatives have been sought to attenuate the effects caused by salt stress on crops, among which the exogenous application of hydrogen peroxide $\left(\mathrm{H}_{2} \mathrm{O}_{2}\right)$, in the form of spray and/or in the pre-treatment of seeds at low concentrations, has proved to be promising in the acclimation of crops to salt stress (Gondim et al., 2011). In addition, $\mathrm{H}_{2} \mathrm{O}_{2}$ works as a signaling molecule in plants under biotic and abiotic stresses, being involved in several processes such as root gravitropism, tolerance to oxygen deficiency, strengthening of cell wall, senescence, photosynthesis, stomatal closure and in the control of cell cycle (Gechev et al., 2006; Petrov \& Breusegem, 2012).

This study aimed to evaluate the gas exchanges and photosynthetic pigments of soursop seedlings cv. 'Morada Nova' irrigated with saline waters and subjected to exogenous application of hydrogen peroxide.

\section{Material and Methods}

The study was conducted in the period from May to October 2017, using $2 \mathrm{dm}^{3}$ plastic bags, under greenhouse conditions at the Center of Technology and Natural Resources of the Federal University of Campina Grande (CTRN/UFCG), located in the municipality of Campina Grande, PB, Brazil, situated by the geographic coordinates $7^{\circ} 15^{\prime} 18^{\prime \prime} \mathrm{S}$ and $35^{\circ}$ 52 ' 28 " W, at mean altitude of $550 \mathrm{~m}$.

The treatments resulted from the combination of five levels of irrigation water electrical conductivity - ECw (0.7; 1.4; 2.1; 2.8 and $3.5 \mathrm{dS} \mathrm{m}^{-1}$ ) and five concentrations of hydrogen peroxide $-\mathrm{H}_{2} \mathrm{O}_{2}(0,25,50,75$ and $100 \mu \mathrm{M})$, arranged in randomized blocks, in $5 \times 5$ factorial scheme, with four replicates and three plants per plot, totaling 300 plants.
The levels of irrigation water electrical conductivity (1.4; 2.1; 2.8 and $3.5 \mathrm{dS} \mathrm{m}^{-1}$ ) were prepared by dissolving the salts $\mathrm{NaCl}, \mathrm{CaCl}_{2} \cdot 2 \mathrm{H}_{2} \mathrm{O}$ and $\mathrm{MgCl}_{2} \cdot 6 \mathrm{H}_{2} \mathrm{O}$, in equivalent proportion of $7: 2: 1$, respectively, in water from the local supply system $\left(\mathrm{ECw}=1.10 \mathrm{dS} \mathrm{m}^{-1}\right)$. This proportion is commonly found in sources of water used for irrigation in small properties of the Northeast region (Medeiros et al., 2003), based on the relationship between $\mathrm{ECw}$ and the concentration of salts recommended by Richards (1954). The level of $0.7 \mathrm{dS} \mathrm{m}^{-1}$ was obtained by diluting water from the local supply system in rainwater $\left(\mathrm{ECw}=0.02 \mathrm{dS} \mathrm{m}^{-1}\right)$.

The plastic bags were filled with $2.6 \mathrm{~kg}$ of dry substrate composed of soil (84\%), sand (15\%) and humus (1\%). The soil used in the experiment was a eutrophic Regolithic Neosol of sandy loam texture, collected in the $0-20 \mathrm{~cm}$ layer, from the rural area of the municipality of Lagoa Seca, PB, properly pounded to break up clods and sieved. Its physical and chemical characteristics were determined according to methodology proposed by Donagema et al. (2011): Exchangeable $\mathrm{Ca}^{2+}, \mathrm{Mg}^{2+}$, $\mathrm{Na}^{+}, \mathrm{K}^{+}, \mathrm{Al}^{3+}+\mathrm{H}^{+}=2.60 ; 3.66 ; 0.16 ; 0.22$ and $1.93 \mathrm{cmol} \mathrm{kg}^{-1}$, respectively; $\mathrm{pH}$ (water 1:2.5) $=5.9$; ECse $=1.0 \mathrm{dS} \mathrm{m}^{-1}$; organic matter $=1.36 \%$; sand, silt and clay $=732.9,142.1$, and $125.0 \mathrm{~g} \mathrm{~kg}^{-1}$, respectively; bulk density $=1.39 \mathrm{~kg} \mathrm{dm}^{-3}$; moisture content at 33.42 and $1519.5 \mathrm{kPa}=11.98$ and $4.32 \mathrm{dag} \mathrm{kg}^{-1}$, respectively.

The seeds used in the experiment were obtained from fruits harvested in a commercial orchard located in the municipality of Macaparana, PE. Seeds were extracted manually, air dried, and their dormancy was broken by means of a distal cut to the embryo, according to methodology proposed by Mendonça et al. (2007).

Prior to sowing, the seeds were subjected to a pre-treatment with hydrogen peroxide, in which they were soaked at the concentrations of the respective treatments for a period of $24 \mathrm{~h}$, whereas seeds of the control treatment $(0 \mu \mathrm{M})$ were soaked in distilled water for the same period of time. Then, sowing was carried out by planting three seeds of soursop cv. 'Morada Nova' at $3 \mathrm{~cm}$ depth, equidistantly distributed. At 20 days after germination, thinning was performed leaving only one plant per bag with highest vigor.

Prior to sowing, the moisture content in the soil was increased to the maximum retention capacity using the water according to each treatment. After sowing, irrigation was performed daily, applying in each plastic bag a water volume sufficient to maintain the soil close to field capacity. The applied volume was determined according to plant water needs, estimated by water balance by subtracting the volume drained from the volume applied in the previous irrigation, plus a leaching fraction of 0.10 , applied every 20 days, in order to control the excessive accumulation of salts in the root zone.

Fertilization with nitrogen, potassium and phosphorus was applied as topdressing, based on the methodology described by Novais et al. (1991). The quantities of $0.58 \mathrm{~g}$ of urea, $0.65 \mathrm{~g}$ of potassium chloride and $1.56 \mathrm{~g}$ of monoammonium phosphate, equivalent to 100,150 and $300 \mathrm{mg} \mathrm{kg}^{-1}$ of the substrate of $\mathrm{N}$, $\mathrm{K}_{2} \mathrm{O}$ and $\mathrm{P}_{2} \mathrm{O}_{5}$, respectively, were applied as topdressing in four equal portions through fertigation, at 15 day intervals, with the first application at 15 days after sowing (DAS). In order to meet deficiencies of micronutrients, the leaves were sprayed 
at 60 and 100 DAS with $2.5 \mathrm{~g} \mathrm{~L}^{-1}$ of Ubyfol [(N (15\%); $\mathrm{P}_{2} \mathrm{O}_{5}$ (15\%); $\mathrm{K}_{2} \mathrm{O}(15 \%) ; \mathrm{Ca}(1 \%) ; \mathrm{Mg}(1.4 \%) ; \mathrm{S}(2.7 \%) ; \mathrm{Zn}(0.5 \%) ;$ $\mathrm{B}(0.05 \%) ; \mathrm{Fe}(0.5 \%) ; \mathrm{Mn}(0.05 \%) ; \mathrm{Cu}(0.5 \%) ; \mathrm{Mo}(0.02 \%)]$.

Foliar application of $\mathrm{H}_{2} \mathrm{O}_{2}$ was carried out manually using a sprayer at $17 \mathrm{~h}$, with solution corresponding to concentration of each treatment, at 90,105 and 120 DAS, spraying the abaxial and adaxial sides of the leaves in order to ensure complete wetting. Control treatment plants were not treated with spraying.

At 120 DAS, gas exchanges were measured based on stomatal conductance $\left(\mathrm{mol} \mathrm{H} \mathrm{H}_{2} \mathrm{O}^{-2} \mathrm{~s}^{-1}\right)$, transpiration $\left(\mathrm{mmol} \mathrm{H}_{2} \mathrm{O} \mathrm{m}^{-2} \mathrm{~s}^{-1}\right), \mathrm{CO}_{2}$ assimilation rate $\left(\mu \mathrm{mol} \mathrm{m} \mathrm{m}^{-2} \mathrm{~s}^{-1}\right)$ and internal $\mathrm{CO}_{2}$ concentration $\left(\mu \mathrm{mol} \mathrm{m}^{-2} \mathrm{~s}^{-1}\right)(\mathrm{CI})$ in the third leaf, counted from the apex, with irradiation of $1200 \mu \mathrm{mol}$ photons $\mathrm{m}^{-2} \mathrm{~s}^{-1}$ and air flow rate of $200 \mathrm{~mL} \mathrm{~min}^{-1}$, using the portable photosynthesis meter "LCPro+" of ADC BioScientific Ltda. These data were used to quantify the instantaneous water use efficiency (WUEI) (A/E) $\left[\left(\mu \mathrm{mol} \mathrm{m}^{-2} \mathrm{~s}^{-1}\right)\left(\mathrm{mol} \mathrm{H}_{2} \mathrm{O} \mathrm{m}^{-2} \mathrm{~s}^{-1}\right)^{-1}\right]$ and instantaneous carboxylation efficiency (EICI) (A/Ci)

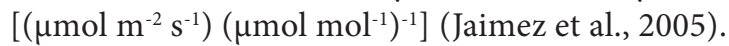

Photosynthetic pigments (chlorophylls $\mathrm{a}$ and $\mathrm{b}$ and carotenoids) were quantified by following the laboratory method developed by Arnon (1949), in which plant extracts are obtained from samples of discs of the third mature leaf from the apex. These extracts were used to determine the concentrations of chlorophylls $\mathrm{a}$ and $\mathrm{b}$ and carotenoids in the solutions using a spectrophotometer at the absorbance (ABS) wavelengths $(470,646$, and $663 \mathrm{~nm})$, using the following equations: Chlorophyll a $($ Chla $)=(12.21 \times$ ABS663 $)-(2.81 \mathrm{x}$ ABS646); Chlorophyll b (Chlb) $=(20.13 \times$ ABS64 $)-(5.03 \times$ ABS663) and Carotenoids (Car) $=[(1000 \times$ ABS470 $)-(1.82$ $\mathrm{x}$ Chla $)-(85.02 \times \mathrm{Chlb})] / 198$. The obtained values for the contents of chlorophylls a and b and carotenoids in the leaves were expressed in $\mathrm{mg} \mathrm{g}^{-1} \mathrm{FM}$ (fresh matter).

The collected data were subjected to analysis of variance by F test at 0.05 and 0.01 probability levels and, when significant, linear and quadratic polynomial regression analysis was carried out using the statistical program Sisvar (Ferreira, 2014).

\section{Results AND Discussion}

Based on F test (Table 1), irrigation water salinity significantly affected stomatal conductance (gs), transpiration (E), $\mathrm{CO}_{2}$ assimilation rate (A), internal $\mathrm{CO}_{2}$ concentration (CI), instantaneous carboxylation efficiency (EICI) and instantaneous water use efficiency (WUEI). The concentrations of hydrogen peroxide and the interaction between factors (Salinity levels - SL x Hydrogen Peroxide - $\mathrm{H}_{2} \mathrm{O}_{2}$ ) had significant effect on gs, E and A.

The increase in irrigation water electrical conductivity negatively affected the stomatal conductance of soursop plants cv. 'Morada Nova' in the control treatment, i.e., those which did not receive exogenous application of $\mathrm{H}_{2} \mathrm{O}_{2}$. According to the regression equation (Figure 1A), there was a linear effect, with reduction of $13.64 \%$ per unit increase in $\mathrm{ECw}$. In relative terms, stomatal conductance decreased by $42.23 \%$ between plants subjected to the highest level of salinity $\left(3.5 \mathrm{dS} \mathrm{m}^{-1}\right)$ and plants at the lowest level $\left(0.7 \mathrm{dS} \mathrm{m}^{-1}\right)$. However, $\mathrm{H}_{2} \mathrm{O}_{2}$ concentrations of 25 and $50 \mu \mathrm{M}$ were able to attenuate the deleterious effects of water salinity from the level of $1.4 \mathrm{dS} \mathrm{m}^{-1}$, since the value of gs is higher than the control, up to $2.5 \mathrm{dS} \mathrm{m}^{-1}$ and the concentration of $75 \mu \mathrm{M}$ from $2.3 \mathrm{dS} \mathrm{m}^{-1}$, with value of gs is higher than the control, up to $2.6 \mathrm{dS} \mathrm{m}^{-1}$. The concentration of $25 \mu \mathrm{M}$ was the most efficient one, whereas the concentration of $100 \mu \mathrm{M}$ intensified the negative effect of salinity.

The increase of stomatal conductance in soursop plants cv. 'Morada Nova' indicates a recovery in the stomatal movement, possibly signaled by the exogenous application of $\mathrm{H}_{2} \mathrm{O}_{2}$. Pre-exposure of plants to moderate stresses or to signaling metabolites such as $\mathrm{H}_{2} \mathrm{O}_{2}$ may result in a metabolic signaling in the cell (increase of metabolites and/or antioxidant enzymes) and, therefore, lead to better physiologic performance when the plant is exposed to more severe conditions of stress (Forman et al., 2010).

By analyzing the interaction between irrigation water salinity and $\mathrm{H}_{2} \mathrm{O}_{2}$ concentrations on the transpiration of soursop plants cv. 'Morada Nova', according to the regression equation (Figure 1B), it is possible to note that the $\mathrm{H}_{2} \mathrm{O}_{2}$ concentration of $25 \mu \mathrm{M}$ led to higher transpiration when compared to the values of plants in the control treatment $(0 \mu \mathrm{M})$ for all studied levels of salinity. The other $\mathrm{H}_{2} \mathrm{O}_{2}$ concentrations intensified the deleterious effects of water salinity. The reductions per unit increase in ECw were, respectively, 12.57, 9.23, 15.41, 17.33 and $18.58 \%$ for the concentrations of $0,25,50,75$ and $100 \mu \mathrm{M}$.

$\mathrm{CO}_{2}$ assimilation rate decreased linearly with increasing electrical conductivity of irrigation water. According to the regression equation (Figure $2 \mathrm{~A}$ ), in plants of the control treatment $(0 \mu \mathrm{M})$, there was a linear reduction of $21.79 \%$ per unit increase in $\mathrm{ECw}$, i.e., reduction of $72.01 \%$ in the $\mathrm{CO}_{2}$ assimilation rate of plants irrigated with water of highest

Table 1. Summary of F test for stomatal conductance (gs), transpiration (E), $\mathrm{CO}_{2}$ assimilation rate (A), internal $\mathrm{CO}_{2}$ concentration (CI), instantaneous carboxylation efficiency (EICI) and instantaneous water use efficiency (WUEI) of soursop plants cv. 'Morada Nova' irrigated with saline waters and subjected to exogenous application of hydrogen peroxide, at 120 days after sowing

\begin{tabular}{|c|c|c|c|c|c|c|}
\hline \multirow{2}{*}{ Source of variation } & \multicolumn{6}{|c|}{ F Test } \\
\hline & Gs & $\mathbf{E}$ & A & Cl & EICI & WUE \\
\hline Salinity levels (SL) & $\star \star$ & *夫 & ** & $\star$ & $\star \star$ & $\star \star$ \\
\hline Linear regression & ** & $\star \star$ & ** & ** & ** & ** \\
\hline Quadratic regression & ns & ns & ns & ns & ns & ns \\
\hline Hydrogen Peroxide $\left(\mathrm{H}_{2} \mathrm{O}_{2}\right)$ & $\star \star$ & ** & ** & ns & ns & ns \\
\hline Linear regression & ** & * & * & ns & ns & ns \\
\hline Quadratic regression & ns & $\star \star$ & ** & ns & ns & ns \\
\hline Interaction $\left(\mathrm{SL} \times \mathrm{H}_{2} \mathrm{O}_{2}\right.$ ) & $\star \star$ & $\star \star$ & $\star \star$ & ns & ns & ns \\
\hline Blocks & ns & ns & ns & ns & ns & ns \\
\hline CV $(\%)$ & 19.99 & 14.66 & 17.88 & 18.94 & 25.30 & 23.45 \\
\hline
\end{tabular}

ns, **, ${ }^{*}$ Respectively, not significant, significant at $\mathrm{p}<0.01$ and $\mathrm{p}<0.05$ 
A.

$\bullet 0 \mu \mathrm{M} \backsim 25 \mu \mathrm{M} \bullet 50 \mu \mathrm{M} \circ 75 \mu \mathrm{M} \boldsymbol{\Delta} 100 \mu \mathrm{M}$

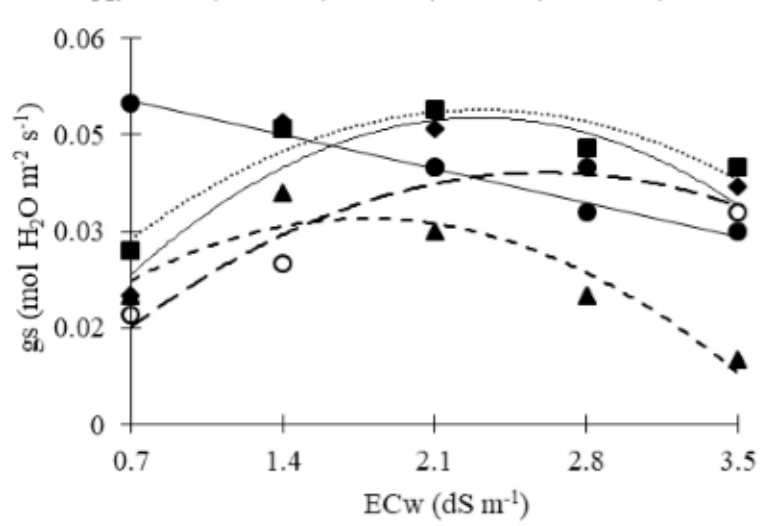

B. $\bullet \mu \mathrm{M} \bullet 25 \mu \mathrm{M} \bullet 50 \mu \mathrm{M} \quad 075 \mu \mathrm{M} \quad \Delta 100 \mu \mathrm{M}$

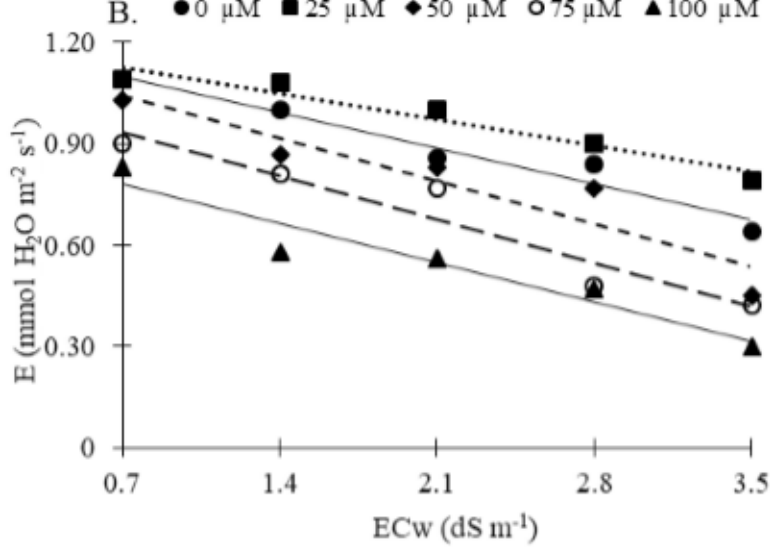

\begin{tabular}{|c|c|}
\hline Equations referring to the Figure 1A & Equations referring to the Figure 1B \\
\hline $\mathrm{y}_{(0 \mathrm{uM})}=0.0557-0.0076^{4 *} \times \quad \mathrm{R}^{2}=0.98$ & $\mathrm{y}_{(0, \mu \mathrm{Ml})}=1.204-0.1514^{* 4} \times \quad \mathrm{R}^{2}=0.95$ \\
\hline $\mathrm{y}_{(25 \mathrm{uM})}=0.0076+0.0357^{\mathrm{ns}} \mathrm{x}-0.0077^{* 0} \mathrm{x}^{2} \mathrm{R}^{2}=0.87$ & $\mathrm{y}_{(25 \mathrm{uM})}=1.206-0.1114^{*} \times \mathrm{R}^{2}=0.94$ \\
\hline $\mathrm{y}_{(50 \mathrm{uM})}=-0.0026+0.0451^{\mathrm{n} 5} \mathrm{x}-0.0099^{* 4} \mathrm{x}^{2} \mathrm{R}^{2}=0.72$ & $\mathrm{y}_{(50 u M)}=1.168-0.18^{\circ *} \mathrm{x} \quad \mathrm{R}^{2}=0.87$ \\
\hline $\mathrm{y}_{\mathrm{n}} \mathrm{uMn}=-0.0056+0.0343^{\mathrm{n} 5} \mathrm{x}-0.0066^{44} \mathrm{x}^{2} \mathrm{R}^{2}=0.91$ & $\mathrm{y}_{(75 \mathrm{uM})}=1.063-0.1843^{* 4} \times \quad \mathrm{R}^{2}=0.91$ \\
\hline $\mathrm{y}_{(100 \mathrm{MN}}=0.006+0.0291^{\mathrm{n} s} \mathrm{x}-0.0082^{* 4} \mathrm{x}^{2} \quad \mathrm{R}^{2}=0.87$ & $\mathrm{y}_{000 \mathrm{uN}}=0.899-0.1671^{\circ \times} \times R^{2}=0.92$ \\
\hline
\end{tabular}

Figure 1. Stomatal conductance - gs (A) and transpiration - E (B) of soursop plants cv. 'Morada Nova', as a function of the interaction between irrigation water electrical conductivity- ECW and hydrogen peroxide concentrations
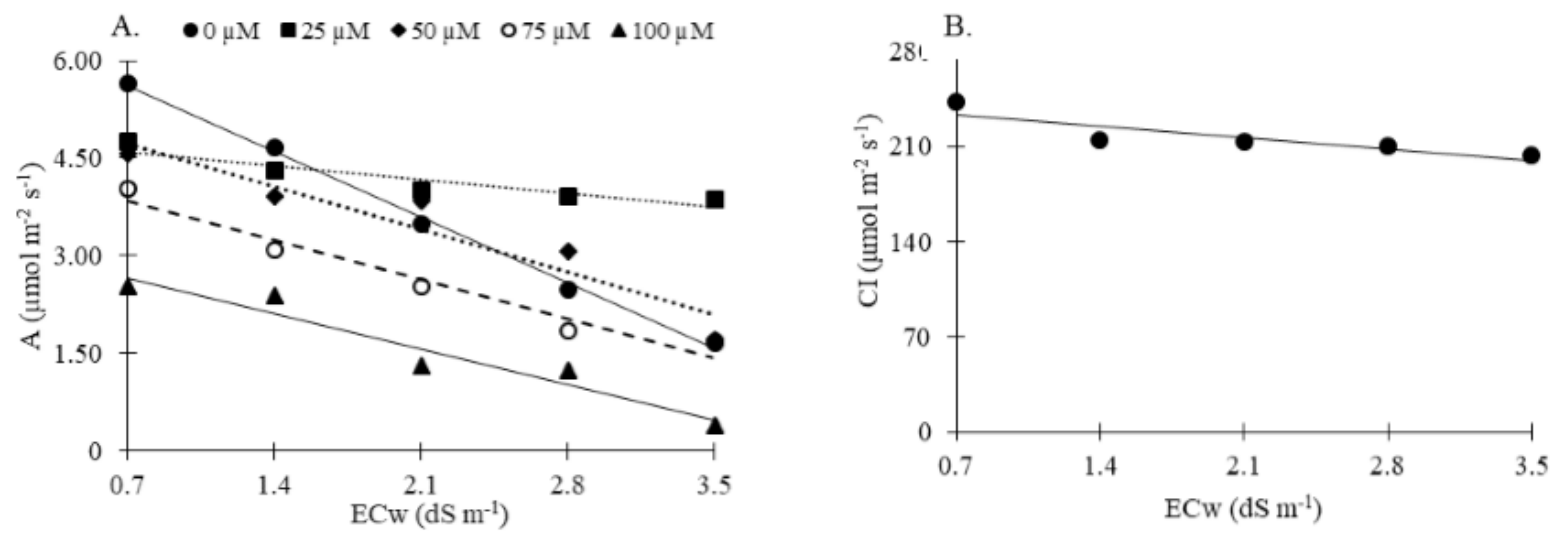

\begin{tabular}{|c|c|}
\hline Equations referring to the Figure $2 \mathrm{~A}$ & Equation referring to the Figure $2 \mathrm{~B}$ \\
\hline $\mathrm{y}_{(0 \mathrm{uM})}=6.622-1.4429^{\circ} \times \quad \mathrm{R}^{2}=0.99$ & $\mathrm{y}=242.1-12.101^{\circ 0} \times \mathrm{R}^{2}=0.77$ \\
\hline $\mathrm{y}_{(25 \mathrm{uM})}=4.812-0.3057^{+4} \mathrm{x} \quad \mathrm{R}^{2}=0.86$ & \\
\hline $\mathrm{y}_{(50 \mathrm{uM})}=5.387-0.9386^{* 4} \mathrm{x} \quad \mathrm{R}^{2}=0.90$ & \\
\hline $\mathrm{y}_{(75 \mathrm{uM})}=4.434-0.86^{4 *} \mathrm{x} \quad \mathrm{R}^{2}=0.95$ & \\
\hline $\mathrm{y}_{(100 \mathrm{uM})}=3.2012-0.7766^{\circ *} \times \mathrm{R}^{2}=0.93$ & \\
\hline
\end{tabular}

Figure 2. $\mathrm{CO}_{2}$ assimilation rate - A (A) as a function of the interaction between irrigation water electrical conductivity (ECw) and hydrogen peroxide concentrations, and internal $\mathrm{CO}_{2}$ concentration - $\mathrm{CI}(\mathrm{B})$ as a function of ECW

salinity level $\left(3.5 \mathrm{dS} \mathrm{m}^{-1}\right)$, compared to the lowest level $\left(0.7 \mathrm{dS} \mathrm{m}^{-1}\right)$. However, there was an increase of $2.17 \mu \mathrm{mol} \mathrm{m}^{-2} \mathrm{~s}^{-1}$ in the $\mathrm{CO}_{2}$ assimilation rate of soursop plants cv. 'Morada Nova' subjected to the $\mathrm{H}_{2} \mathrm{O}_{2}$ concentration of $25 \mu \mathrm{M}$ and irrigated with $3.5 \mathrm{dS} \mathrm{m}^{-1}$ water, compared to the control treatment $(0 \mu \mathrm{M})$ in respective treatment.

As observed in the variables gs and $\mathrm{E}$ (Figures $1 \mathrm{~A}$ and B), the $\mathrm{H}_{2} \mathrm{O}_{2}$ concentration of $100 \mu \mathrm{M}$ did not attenuate the deleterious effect of salinity on the $\mathrm{CO}_{2}$ assimilation rate of soursop plants cv. 'Morada Nova'; the opposite occurred. Thus, it can be inferred that the excess of reactive oxygen species had a toxic effect, mainly caused by the oxidative stress.

The salt stress reduced stomatal conductance, transpiration and $\mathrm{CO}_{2}$ assimilation rate in soursop plants cv. 'Morada Nova', comparing to control treatment $\left(0.7 \mathrm{dS} \mathrm{m}^{-1}\right)$. Closure of stomata in plants results in a restriction to $\mathrm{CO}_{2}$ entry in leaf mesophyll cells, which may increase the susceptibility to photochemical damage because the reduction in $\mathrm{CO}_{2}$ assimilation rate causes excessive light energy in the photosystem II (Silva et al., 2010).

The beneficial effect of hydrogen peroxide at low concentrations may be associated with its role as a signaling molecule, regulating several pathways, including responses to saline stress (Baxter et al., 2014). Therefore, $\mathrm{H}_{2} \mathrm{O}_{2}$ is related to the regulation of several mechanisms under conditions of abiotic and biotic stresses (Malolepsza \& Rózalska, 2005).

The internal $\mathrm{CO}_{2}$ concentration (CI) of soursop plants $\mathrm{cv}$. 'Morada Nova' decreased linearly in response to the increasing levels of $\mathrm{ECw}$ and, according to the regression equation (Figure 2B), it can be noted that at ECw of $1.4 \mathrm{dS} \mathrm{m}^{-1}$ there was a reduction of $3.62 \%$ compared to the control treatment $\left(0.7 \mathrm{dS} \mathrm{m}^{-1}\right)$; for ECw levels of 2.1, 2.8 and $3.5 \mathrm{dS} \mathrm{m}^{-1}$, the reductions were respectively equal to $7.25,10.87$ and $14.5 \%$. These reductions of internal $\mathrm{CO}_{2}$ concentration with increase in salinity levels observed in soursop cv. 'Morada Nova' are 
a common response of plants to salt stress, which occurs probably due to the lower $\mathrm{CO}_{2}$ diffusion in the substomatal chamber due to stomatal closure (Oliveira et al., 2017).

For the instantaneous carboxylation efficiency (EICI), irrigation water salinity had a negative effect and, according to the regression equation (Figure $3 \mathrm{~A}$ ), there was a reduction in EICI of $18.49 \%$ per unit increase in electrical conductivity of water, i.e., reductions of $59.47 \%$ in the EICI of plants irrigated with water of highest salinity $\left(3.5 \mathrm{dS} \mathrm{m}^{-1}\right)$, compared to the lowest level (0.7 $\left.\mathrm{dS} \mathrm{m}^{-1}\right)$. According to Taiz \& Zeiger (2017), as the stress becomes more severe, the dehydration of mesophyll cells inhibits photosynthesis, thus damaging the metabolism and consequently hampering carboxylation efficiency.

Instantaneous water use efficiency (WUEI) was also negatively affected by irrigation water salinity (Figure 3B). The linear model fitted indicates that irrigation using water with ECw of $0.7 \mathrm{dS} \mathrm{m}^{-1}$ (control treatment) led to the highest WUEI [ $4.48 \mu \mathrm{mol} \mathrm{m}^{-2} \mathrm{~s}^{-1}\left(\mathrm{~mol} \mathrm{H}_{2} \mathrm{O} \mathrm{m}^{-2} \mathrm{~s}^{-1}\right)^{-1}$ ], whereas the highest level of salinity $\left(3.5 \mathrm{dS} \mathrm{m}^{-1}\right)$ caused the lowest value $\left[3.37 \mu \mathrm{mol} \mathrm{m}^{-2} \mathrm{~s}^{-1}\right.$ $\left.\left(\mathrm{mol} \mathrm{H}_{2} \mathrm{O} \mathrm{m}^{-2} \mathrm{~s}^{-1}\right)^{-1}\right]$, i.e., a reduction of $24.74 \%\left[1.11 \mu \mathrm{mol} \mathrm{m}^{-2} \mathrm{~s}^{-1}\right.$ $\left(\mathrm{mol} \mathrm{H}_{2} \mathrm{O} \mathrm{m}^{-2} \mathrm{~s}^{-1}\right)^{-1}$ ] between the highest $\left(3.5 \mathrm{dS} \mathrm{m}^{-1}\right)$ and lowest $\left(0.7 \mathrm{dS} \mathrm{m}^{-1}\right)$ levels of irrigation water salinity. It can be inferred the irrigation water salinity directly affects WUEI in soursop plants cv. 'Morada Nova'. Thus, the reduction of WUEI observed in the present study may be related to the accumulation of salts in the soil along the crop cycle, a situation that contributes to the reduction of the osmotic potential of the soil and, consequently caused greater difficulty for water absorption by plants (Nobre et al., 2014).

The F test (Table 2$)$ shows significant effect $(\mathrm{p}<0.01)$ of irrigation water salinity levels on chlorophyll a (Chla) and chlorophyll b (Chlb). The hydrogen peroxide concentrations and the interaction between factors $\left(\mathrm{SL} \mathrm{x} \mathrm{H}_{2} \mathrm{O}_{2}\right)$ significantly influenced $(\mathrm{p}<0.01)$ all variables analyzed.

The regression equation (Figure $4 \mathrm{~A}$ ) indicates that, in plants of the control treatment $(0 \mu \mathrm{M})$, there was a reduction in Chla content of $15.2 \%$ per unit increase in irrigation water electrical conductivity. On the other hand, in soursop plants cv. 'Morada Nova' subjected to treatments with hydrogen peroxide concentrations of 25 and $50 \mu \mathrm{M}$, the deleterious

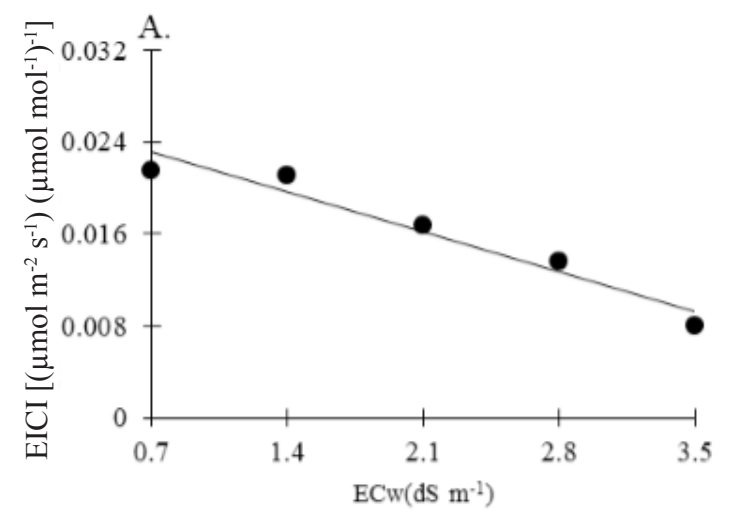

Table 2. Summary of F test for chlorophyll a (Chla), chlorophyll $\mathrm{b}$ (Chlb) and carotenoids (Car) of soursop plants cv. 'Morada Nova' irrigated with saline waters and subjected to exogenous application of hydrogen peroxide, at 140 days after sowing

\begin{tabular}{|c|c|c|c|}
\hline \multirow{2}{*}{ Source of variation } & \multicolumn{3}{|c|}{ F Test } \\
\hline & Chla & Chlb & Car \\
\hline Salinity levels (SL) & ** & $\star *$ & ns \\
\hline Linear regression & ** & ** & ns \\
\hline Quadratic regression & ns & ns & ns \\
\hline Hydrogen Peroxide $\left(\mathrm{H}_{2} \mathrm{O}_{2}\right)$ & $\star \star$ & ** & ** \\
\hline Linear regression & ns & ns & * \\
\hline Quadratic regression & $\star \star$ & $\star \star$ & ns \\
\hline Interaction $\left(\mathrm{SL} \times \mathrm{H}_{2} \mathrm{O}_{2}\right.$ ) & ** & ** & ** \\
\hline Blocks & ns & ns & ns \\
\hline CV (\%) & 8.11 & 15.69 & 14.87 \\
\hline
\end{tabular}

effects of salinity on Chla content were attenuated. Plants under the highest level of salinity $\left(3.5 \mathrm{dS} \mathrm{m}^{-1}\right)$ subjected to $50 \mu \mathrm{M}$ of $\mathrm{H}_{2} \mathrm{O}_{2}$ obtained the highest means of Chla (4.92 $\mathrm{mg} \mathrm{g}^{-1} \mathrm{FM}$ ), which represented an increase of $2.32 \mathrm{mg} \mathrm{g}^{-1}$ compared to the control treatment $(0 \mu \mathrm{M})$ at the same salinity level. However, the concentrations of 75 and $100 \mu \mathrm{M}$ did not attenuate the negative effects of irrigation water salinity on the Chla contents of soursop plants cv. 'Morada Nova'.

For chlorophyll b (Chlb) (Figure 4B), the $\mathrm{H}_{2} \mathrm{O}_{2}$ concentration of $50 \mu \mathrm{M}$ led to the highest means, which corresponded to $1.59,1.78$ and $1.66 \mathrm{mg} \mathrm{g}^{-1} \mathrm{FM}$, when plants were irrigated with the respective ECw levels of 2.1, 2.8 and $3.5 \mathrm{dS} \mathrm{m}^{-1}$. In addition, plants in the control treatment $(0 \mu \mathrm{M})$ (Figure $4 \mathrm{~B})$ had reduction of $13.87 \%$ in chlorophyll $b$ content per unit increase in ECw. However, plants subjected to concentration of $50 \mu \mathrm{M}$ and exposed to salt stress at the highest ECw level (3.5 $\mathrm{dS} \mathrm{m}^{-1}$ ) showed increase of $0.875 \mathrm{mg} \mathrm{g}^{-1} \mathrm{FM}$ in the chlorophyll b content, compared to those subjected to the control treatment. The reduction in chlorophyll $\mathrm{b}$ content observed in plants of the control treatment $(0 \mu \mathrm{M})$ may be attributed to the increase in the activity of the chlorophyllase enzyme, which degrades molecules of this photosynthesizing pigment (Freire et al., 2013). Gondim (2012), evaluating foliar pre-treatment with $\mathrm{H}_{2} \mathrm{O}_{2}$ as a strategy to minimize the deleterious effects of salinity on corn plants, observed that the highest contents of chlorophyll were obtained in plants pre-

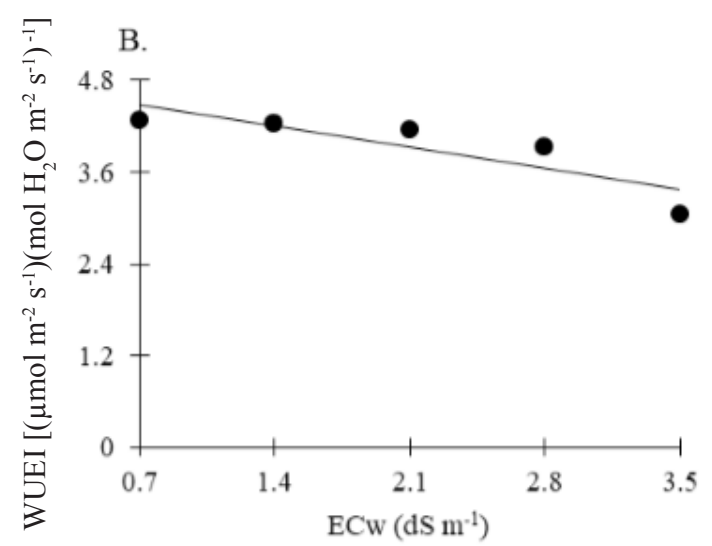

\begin{tabular}{cc}
\hline Equations referring to the Figure 3A & Equation referring to the Figure 3B \\
\hline $\mathrm{y}=0.0265-0.0049^{* *} \times \mathrm{R}^{2}=0.94$ & $\mathrm{y}=4.755-0.3957^{\circ *} \times \mathrm{R}^{2}=0.73$
\end{tabular}

Figure 3. Instantaneous carboxylation efficiency - EICI (A) and instantaneous water use efficiency - WUEI (B) of soursop plants as a function of irrigation water salinity 

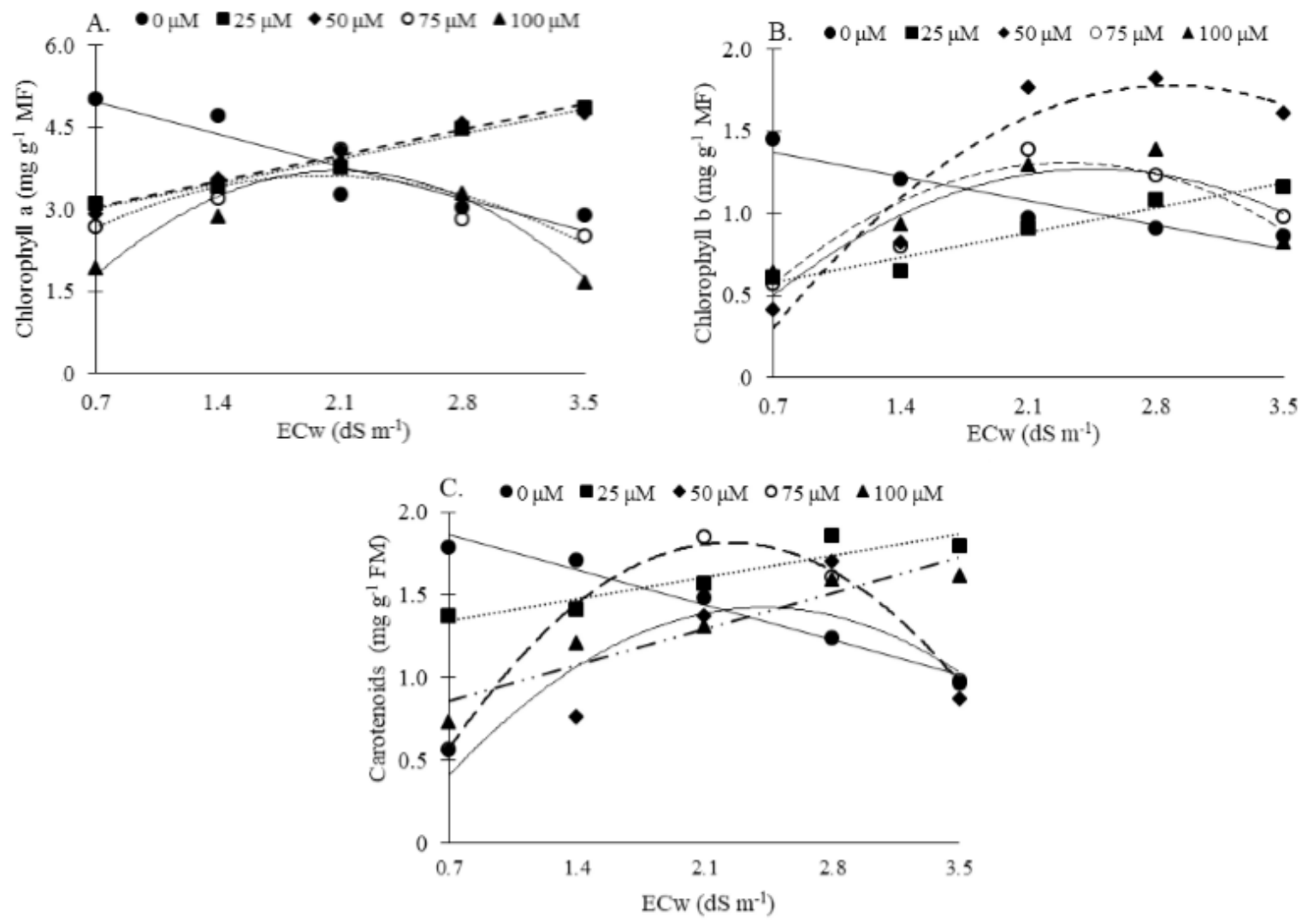

\begin{tabular}{|c|c|c|}
\hline Equations referring to the Figure $4 \mathrm{~A}$ & Equations referring to the Figure 4B & Equations referring to the Figure $4 \mathrm{C}$ \\
\hline $\mathrm{y}(0, \mu \mathrm{M})=5.564-0.8457^{+2} \times R^{2}=0.88$ & $\mathrm{Y}(0 \mu \mathrm{M})=1.524-0.2114^{2+2} \times \mathrm{R}^{2}=0.90$ & $\mathrm{Y}(0 \mu \mathrm{M})=2.071-0.3014^{4-2} \times R^{2}=0.97$ \\
\hline $\mathrm{y}_{(25 \mu \mathrm{M})}=2.558+0.6514^{* 4} \mathrm{x} \quad \mathrm{R}^{2}=0.98$ & $\mathrm{y}_{(25 \mu \mathrm{M})}=0.423+0.2186^{*-4} \times \mathrm{R}^{2}=0.95$ & $\mathrm{y}_{(25 \mu \mathrm{M})}=1.209+0.1871^{*-4} \times \mathrm{R}^{2}=0.87$ \\
\hline $\mathrm{y}(50 \mu \mathrm{M})=2.562+0.6743^{* 4} \times R^{2}=0.97$ & $\mathrm{y}(50 \mu \mathrm{M})=-0.804+1.7959^{n \mathrm{n}} \mathrm{x}-0.312^{* 4} \mathrm{x}^{2} \quad \mathrm{R}^{2}=0.92$ & $y_{(50 \mu M)}=-0.586+1.6555^{n} \mathrm{x} x-0.3411^{*} \mathrm{x}^{2} \quad \mathrm{R}^{2}=0.72$ \\
\hline $\mathrm{y}(75 \mu \mathrm{M})=1.384+2.2255^{\mathrm{n}} \mathrm{x}-0.5554^{*} \mathrm{x}^{2} \quad \mathrm{R}^{2}=0.69$ & $\mathrm{y}_{(75 \mu \mathrm{M})}=-0.236+1.2255^{\mathrm{n}} \mathrm{x}-0.2493^{4 *} \mathrm{x}^{2} \quad \mathrm{R}^{2}=0.85$ & $\mathrm{y}_{(75 \mu \mathrm{M})}=-0.832+2.3667^{\mathrm{n}} \mathrm{x}-0.5292^{4} \mathrm{x}^{2} \quad \mathrm{R}^{2}=0.99$ \\
\hline $2+4.1169^{\text {ns }} \mathrm{x}-0.984^{40} \mathrm{x}^{2} \mathrm{R}^{2}=0.94$ & $\mathrm{y}_{(100 \mu \mathrm{M})}=-0.222+1.3294^{\mathrm{n}} \mathrm{x}-0.2886^{*} \mathrm{x}^{2} \quad \mathrm{R}^{2}=$ & $\mathrm{y}(100 \mu \mathrm{NO})=0.644+0.3086^{\circ *} \times R^{2}=0.89$ \\
\hline
\end{tabular}

Figure 4. Chlorophyll a (A), chlorophyll b (B) and carotenoids (C) of soursop plants cv. 'Morada Nova' as a function of the interaction between irrigation water electrical conductivity - ECw and hydrogen peroxide concentrations

treated with $\mathrm{H}_{2} \mathrm{O}_{2}$ at concentration of $10 \mathrm{mM}$, despite being subjected to salt stress $(80 \mathrm{mM}$ of $\mathrm{NaCl})$.

As regards to the carotenoid content, the regression equation (Figure 4C) shows a linear decreasing effect in the control treatment plants $(0 \mu \mathrm{M})$, with a decrease in carotenoid content of $14.55 \%$ per unit increment of $\mathrm{ECw}$, resulting in reduction of $0.844 \mathrm{mg} \mathrm{g}^{-1} \mathrm{FM}$ in plants irrigated with water of $3.5 \mathrm{dS} \mathrm{m}^{-1}$ relative to the lowest level $\left(0.7 \mathrm{dS} \mathrm{m}^{-1}\right)$. However, it was verified that the plants submitted to hydrogen peroxide had an increase in the carotenoid content with the imposition of salt stress, especially in the concentrations of 25 and $100 \mu \mathrm{M}$, whose increases were, respectively, 0.848 and $0.708 \mathrm{mg} \mathrm{g}^{-1} \mathrm{FM}$, at $3.5 \mathrm{dS} \mathrm{m}^{-1}$, in relation to the control treatment $\left(0.7 \mathrm{dS} \mathrm{m}^{-1}\right)$, indicating that the hydrogen peroxide was effective in the acclimation of soursop plants cv. Morada Nova to saline stress. Carotenoids are pigments that may exert a photoprotective action of the photochemical apparatus, being the increase of carotenoids possibly a defense mechanism, predicting photooxidative damage to chlorophyll molecules (Raven et al., 2007).

The reduction in the content of carotenoids in the control treatment occurred possibly because of the degradation or inhibition in the synthesis of carotenoids, mainly due to photooxidation, leading to damage to photosynthetic membranes, besides affecting other cell processes such as division and expansion (Silva et al., 2014).

\section{Conclusions}

1. As the salt stress increases, there is a reduction in the photosynthetic parameters of soursop plants cv. 'Morada Nova'.

2. Exogenous application of hydrogen peroxide at concentrations of 25 and $50 \mu \mathrm{M}$ attenuated the deleterious effects of salts stress on stomatal conductance, $\mathrm{CO}_{2}$ assimilation rate and chlorophyll a content.

3. Hydrogen peroxide concentrations of 75 and $100 \mu \mathrm{M}$ in interaction with irrigation water salinity cause reductions in transpiration, $\mathrm{CO}_{2}$ assimilation rate and chlorophyll a content of soursop plants cv. 'Morada Nova'.

4. The content of chlorophyll b and carotenoids of soursop cv. 'Morada Nova' had the deleterious effects caused by the salinity of irrigation water mitigated by the exogenous application of hydrogen peroxide in the concentration of $25 \mu \mathrm{M}$.

\section{Literature Cited}

Arnon, D. I. Copper enzymes in isolated chloroplasts: Polyphenoloxidase in Beta vulgaris. Plant Physiology, v.24, p.115, 1949. https://doi.org/10.1104/pp.24.1.1

Barbosa, R. C. A.; Brito, M. E. B.; Sá, F. V. da S.; Soares Filho, W. dos S.; Fernandes, P. D.; Silva, L. de A. Gas exchange of citrus rootstocks in response to intensity and duration of saline stress. Semina: Ciências Agrárias, v.38, p.725-738, 2017. https://doi. org/10.5433/1679-0359.2017v38n2p725 
Baxter, A.; Mittler, R.; Suzuki, N. ROS as key players in plant stress signalling. Journal of Experimental Botany, v.65, p.1229-1240, 2014. https://doi.org/10.1093/jxb/ert375

Bezerra, I. L.; Nobre, R. G.; Gheyi, H. R.; Souza, L. de P.; Pinheiro, F. W. A.; Lima, G. S. de. Morphophysiology of guava under saline water irrigation and nitrogen fertilization. Revista Brasileira de Engenharia Agrícola e Ambiental, v.22, p.32-27, 2018. https://doi. org/10.1590/1807-1929/agriambi.v22n1p32-37

Braga Sobrinho, R. Potencial de exploração de anonáceas no Nordeste do Brasil. In: Semana da Floricultura e Agroindústria, 17, 2010, Fortaleza. Anais... Fortaleza: Embrapa Agroindústria Tropical, 2010. 27p.

Brito, M. E. B.; Fernandes, P. D.; Gheyi, H. R.; Melo, A. S. de; Soares Filho, W. dos S.; Santos, R. T. dos. Sensibilidade à salinidade de híbridos trifoliados e outros porta-enxertos de citros. Revista Caatinga, v.27, p.17-27, 2014.

Cavalcante, L. F.; Rocha, L. F. da; Silva, R. A. R.; Souto, A. G. L.; Nunes, J. C.; Cavalcante, Í. H. L. Produção e qualidade da graviola sob irrigação e cobertura do solo com resíduo de sisal. Magistra, v.28, p.91-101, 2017.

Donagema, G. K.; Campos, D. V. B. de; Calderano, S. B.; Teixeira, W. G.; Viana, J. H. M. (org.). Manual de métodos de análise de solo. 2.ed. Rio de Janeiro: Embrapa Solos, 2011. 230p.

Ferreira, D. F. Sisvar: A guide for its bootstrap procedures in multiple comparisons. Ciência e Agrotecnologia, v.38, p.109-112, 2014 https://doi.org/10.1590/S1413-70542014000200001

Forman, H. J.; Maiorino, M.; Ursini, F. Signaling functions of reactive oxygen species. Biochemistry, v.49, p.835-842, 2010. https://doi. org/10.1021/bi9020378

Freire, J. L. de O.; Cavalcante, L. F.; Nascimento, R. do; Rebequi, A. M. Teores de clorofila e composição mineral foliar do maracujazeiro irrigado com águas salinas e biofertilizante. Revista de Ciências Agrárias, v.36, p.57-70, 2013.

Freitas, A. L. G. E. de; Vilas Boas, F. S.; Pires, M. de M.; São José, A. R. Caracterização da produção e do mercado da graviola (Annona muricata L.) no estado da Bahia. Informações Econômicas, v.43, p.23-34, 2013.

Gechev, T. S.; Breusegem, F. van; Stone, J. M.; Denev, I.; Laloi, C. Reactive oxygen species as signals that modulate plant stress responses and programmed cell death. BioEssays, v.28, p.10911101, 2006. https://doi.org/10.1002/bies.20493

Gondim, F. A. Pré-tratamento foliar com $\mathrm{H}_{2} \mathrm{O}_{2}$ como estratégia para minimizar os efeitos deletérios da salinidade em plantas de milho. Fortaleza: Universidade Federal do Ceará, 2012. 147p. Tese Doutorado

Gondim, F. A.; Gomes Filho, E.; Marques, E. C.; Prisco, J. T. Efeitos do $\mathrm{H}_{2} \mathrm{O}_{2}$ no crescimento e acúmulo de solutos em plantas de milho sob estresse salino. Revista Ciência Agronômica, v.42, p.373-381, 2011. https://doi.org/10.1590/S1806-66902011000200016

Jaimez, R. E.; Rada, F.; Garcia-Núñez, C.; Azócar, A. Seasonal variations in leaf gas exchange of platain cv. Hartón (Musa $\mathrm{AAB}$ ) under different soil water conditions in a humid tropical region. Scientia Horticulturae, v.104, p.79-89, 2005. https://doi. org/10.1016/j.scienta.2004.07.002
Lacerda, C. F. de; Costa, R. N. T.; Bezerra, M. A.; Neves A. L. R.; Sousa, G. G. de; Gheyi, H. R. Estratégias de manejo para uso de água salina na agricultura. In: Gheyi, H. R.; Dias, N. da S.; Lacerda, C. F. de; Gomes Filho, E. (eds.). Manejo da salinidade na agricultura: Estudos básicos e aplicados. Fortaleza: INCTSal, 2016. Cap.21, p.337-352.

Lima, G. S. de; Santos, J. B. dos; Soares, L. A. dos A.; Gheyi, H. R.; Nobre, R. G.; Pereira, R. F. Irrigação com águas salinas e aplicação de prolina foliar em cultivo de pimentão 'All Big'. Comunicata Scientiae, v.7, p.513-522, 2016. https://doi.org/10.14295/cs.v7i4.1671

Malolepsza, U.; Rózalska, S. Nitric oxide and hydrogen peroxide in tomato resistance: Nitric oxide modulates hydrogen peroxide level in o-hydroxyethylorutin-induced resistance to Botrytis cinerea in tomato. Plant Physiology and Biochemistry, v.43, p.623-635, 2005. https://doi.org/10.1016/j.plaphy.2005.04.002

Medeiros, J. F. de. Qualidade de água de irrigação e evolução da salinidade nas propriedades assistidas pelo GAT nos Estados de RN, PB e CE. Campina Grande: Universidade Federal da Paraíba, 2003. 173p. Dissertação Mestrado

Mendonça, V.; Ramos, J. D.; Pio, R.; Gontijo, T. C. A.; Tosta, M. da S. Superação de dormência e profundidade de semeadura de sementes de gravioleira. Revista Caatinga, v.20, p.73-78, 2007.

Nobre, R. G.; Lima, G. S. de; Gheyi, H. R.; Soares, L. A. dos A.; Silva, A. O. da. Crescimento, consumo e eficiência do uso da água pela mamoneira sob estresse salino e nitrogênio. Revista Caatinga, v.27, p.148-158, 2014.

Novais, R. F.; Neves, J. C. L.; Barros, N. F. Ensaio em ambiente controlado. In: Oliveira, A. J. de; Garrido, W. E.; Araújo, J. D. de; Lourenço, S. (eds.). Métodos de pesquisa em fertilidade do solo. Brasília: Embrapa-SEA, 1991. p.189-253. Documentos, 3

Oliveira, W. J. D.; Souza, E. R. D.; Cunha, J. C.; Silva, Ê. F. de F. e; Veloso, V.D. L. Leaf gas exchange in cowpea and $\mathrm{CO}_{2}$ efflux in soil irrigated with saline water. Revista Brasileira de Engenharia Agrícola e Ambiental, v.21, p.32-37, 2017. https://doi.org/10.1590/1807-1929/ agriambi.v21n1p32-37

Petrov, V. D.; Breusegem, F. van. Hydrogen peroxide: A central hub for information flow in plant cells. AoB Plants, v.2012, p.1-13, 2012. https://doi.org/10.1093/aobpla/pls014

Raven, P. H.; Evert, R. F.; Eichhorn, S. E. Biologia vegetal. 7.ed. Rio de Janeiro: Guanabara Koogan, 2007. 728p.

Richards, L. A. Diagnosis and improvement of saline and alkali soils. Washington: U.S. Department of Agriculture, 1954. 160p.

Sá, F. V. da S.; Brito, M. E. B.; Pereira, I. B.; Antônio Neto, P.; Silva, L. de A.; Costa, F. B. da. Balanço de sais e crescimento inicial de mudas de pinheira (Annona squamosa L.) sob substratos irrigados com água salina. Irriga, v.20, p.544-556, 2015. https://doi.org/10.15809/ irriga.2015v20n3p544

Silva, E. D.; Ribeiro, R. V.; Ferreira-Silva, S. L.; Viégas, R. A.; Silveira, J. A. G. Comparative effects of salinity and water stress on photosynthesis, water relations and growth of Jatropha curcas plants. Journal of Arid Environments, v.74, p.1130-1137, 2010. https://doi. org/10.1016/j.jaridenv.2010.05.036

Silva, M. de A.; Santos, C. M. dos; Vitorino, H. dos S.; Rhein, A. F. de L. Pigmentos fotossintéticos e índice Spad como descritores de intensidade do estresse por deficiência hídrica em cana-de-açúcar. Bioscience Journal, v.30, p.173-181, 2014.

Taiz, L.; Zeiger, E.; Møller, I. M.; Murphy, A. Fisiologia e desenvolvimento vegetal. 6.ed. Porto Alegre: Artmed, 2017. 888p. 